\title{
Intracellular Staphylococcus aureus Elicits the Production of Host Very Long-Chain Saturated Fatty Acids with Antimicrobial Activity
}

\author{
Natalia Bravo-Santano ${ }^{1}$, James K. Ellis ${ }^{2,+}$, Yolanda Calle ${ }^{1}$, Hector C. Keun ${ }^{2}{ }^{\circledR}$, \\ Volker Behrends $1, * \mathbb{D}$ and Michal Letek ${ }^{1, * \mathbb{D}}$ \\ 1 Health Sciences Research Centre, University of Roehampton, London SW15 4JD, UK \\ 2 Division of Cancer, Department of Surgery and Cancer, Faculty of Medicine, Imperial College London, \\ London W12 0HS, UK \\ * Correspondence: Volker.Behrends@roehampton.ac.uk (V.B.); Michal.Letek@roehampton.ac.uk (M.L.) \\ + Present Address: The Francis-Crick Institute, London NW1 1ST, UK.
}

Received: 17 June 2019; Accepted: 17 July 2019; Published: 20 July 2019

\begin{abstract}
As a facultative intracellular pathogen, Staphylococcus aureus is able to invade and proliferate within many types of mammalian cells. Intracellular bacterial replication relies on host nutrient supplies and, therefore, cell metabolism is closely bound to intracellular infection. Here, we investigated how S. aureus invasion affects the host membrane-bound fatty acids. We quantified the relative levels of fatty acids and their labelling pattern after intracellular infection by gas chromatography-mass spectrometry (GC-MS). Interestingly, we observed that the levels of three host fatty acids-docosanoic, eicosanoic and palmitic acids-were significantly increased in response to intracellular S. aureus infection. Accordingly, labelling carbon distribution was also affected in infected cells, in comparison to the uninfected control. In addition, treatment of HeLa cells with these three fatty acids showed a cytoprotective role by directly reducing $S$. aureus growth.
\end{abstract}

Keywords: intracellular infection; lipids metabolism; fatty acids; antibacterial effect; Staphylococcus aureus

\section{Introduction}

The Gram-positive Staphylococcus aureus is an opportunistic pathogen, known for its ability to cause nosocomial infections and infect immune-compromised people, e.g., cystic fibrosis patients. It is a facultative intracellular pathogen, carried by about one third of the global human population on the skin and/or in the nasal passages [1,2]. S. aureus is able to invade and proliferate within a wide range of mammalian cells, including both phagocytic and non-phagocytic cells [3-6]. During host cell invasion, $S$. aureus is able to induce profound rearrangements of the host cell cytoskeleton to favor its own internalization, control autophagy to facilitate its replication inside of a pathogen-containing vacuole, and manipulate apoptosis [6]. The intracellular mode of growth could be used by the pathogen to evade host immune recognition and avoid exposure to last-resort antibiotics, such as daptomycin, vancomycin and linezolid [7]. A better understanding of the host-pathogen interaction during intracellular infection could lead to novel therapeutic approaches that could be used in combination with traditional antibiotherapy.

Bacterial pathogens require accessible forms of chemical energy to support intracellular proliferation. Therefore, the interaction between intracellular pathogens and host cell metabolism is an important feature of virulence $[8,9]$. Bacteria need to adapt to the host microenvironment and, consequently, they exploit host metabolic pathways in order to ensure their survival and proliferation within host cells [10-12]. Most of the research on this topic has focused on well-studied intracellular 
pathogens such as Shigella flexneri, Escherichia coli, Listeria monocytogenes, Salmonella typhimurium, Legionella pneumophila and Chlamydia trachomatis [10,13]. For instance, L. pneumophila interacts with the host mitochondria, inducing a Warburg-like effect in the host cell to favor its own replication [14]. S. flexneri re-routes host central carbon metabolism through the glycolytic pathway to obtain an abundant nutrient-flux that allows its intracellular survival [15]. Moreover, intracellular M. tuberculosis requires host cholesterol import to persist inside both macrophages and mice's lungs [16].

In contrast, very little is known about how the host cell metabolism is modulated and exploited by the pathogen $S$. aureus. The host metabolic response of human airway epithelial cells to $S$. aureus infection was recently investigated [17]. Interestingly, a reduction in nutrient uptake as well as an induction of nucleotide biosynthesis were observed in S. aureus-infected cells, although the underlying mechanisms are still unclear [17]. In addition, we recently found that intracellular methicillin-resistant Staphylococcus aureus (MRSA) reroutes host central carbon metabolism, leading to a starvation-induced autophagic flux in MRSA-infected cells [12]. Moreover, MRSA exploits the host AMPK-pathway during intracellular infection and pharmacological AMPK-inhibition hampered S. aureus intracellular proliferation.

Previously, fatty acids have been shown to act as powerful signaling molecules and be involved in different metabolic processes [18] that could be important for intracellular MRSA infection. Furthermore, antimicrobial activities have been described for lipids and particular fatty acids [19-21]. Additionally, host-derived fatty acids and lipids have an importance for intracellular infection as immune modulators [22]. On the other hand, S. aureus can incorporate host derived fatty acids into its own membranes [23]. To shed some light on the metabolism of lipids during cell infection, here we determined the levels and labelling carbon distribution of esterified fatty acids in HeLa cells after intracellular MRSA infection.

\section{Results and Discussion}

\subsection{Levels and Labelling Pattern of Saturated Fatty Acids in HeLa Cells in Response to Intracellular MRSA Infection}

We quantified nine lipid-bound fatty acids in our samples: arachidonic, eicosanoic, docosanoic, linoleic, myristic, oleic, palmitic, palmitoleic and stearic acids. Six of them showed no differences among treatments, such as stearic acid (Figure 1 and Figure S1). However, the absolute levels of two long-chain saturated lipid-bound fatty acids, docosanoic (C22:0) and eicosanoic acid (C20:0), as well as palmitic acid (C16:0), were markedly increased after intracellular MRSA infection (Figure 1). Levels of docosanoic and palmitic acid remained stable in cells exposed to heat-killed bacteria (Figure 1). In contrast, levels of eicosanoic acid significantly increased in cells exposed to heat-killed USA300 bacteria, although the increase was notably higher in MRSA-infected cells (Figure 1). This is suggesting that part of this increase is due to a host-immune-like response. Considering that mostly polyunsaturated eicosanoids have been related to inflammation and are considered a main component of the host innate immune responses [22], the rise of eicosanoic acid (a saturated fatty acid) in the host cell in response to heat-killed bacteria exposure is surprising.

Additionally, we performed carbon-labelling experiments in which one of the two major carbon sources in the medium (glucose and glutamine, respectively) was substituted by universally ${ }^{13} \mathrm{C}$-labeled varieties. This allows quantification of rate of synthesis and carbon flux. Interestingly, the label distribution varies across the three experimental conditions, especially for docosanoic and eicosanoic acids. In MRSA-infected cells, both eicosanoic and docosanoic acids showed a similar labelling distribution, displaying an increase in glucose-derived label (Figure 2 and Figure S2). The majority of label was detected in the $m+2$ and $m+4$ isotopologues (Figure S3). ISA flux analysis [24] indicated that these long-chain fatty acids were mostly the result of fatty acid elongation of existing fatty acids rather than de novo synthesis of whole molecule (model parameters for eicosanoic acid from infection HeLa cells grown in ${ }^{13} \mathrm{C}_{6}$ glucose-labelled cultures-fractional enrichment $D$ 0.44; de novo synthesis, $g(t), 0.26$; elongation 0.74$)$. This is broadly in agreement with the fact that we see no or little increased enrichment in palmitate or stearate. As ISA flux is ideal for modeling the production of saturated long 
and very-long chain fatty acids, we also used the recently developed FASA package [25]. The resulting parameters are broadly comparable, though they show a lesser dependence on elongation ( $D$ 0.6; synthesis 0.31 ; import (present before addition of label) 0.34 ; elongation (combined) 0.35 ). The increase in glucose-derived label of both eicosanoic and docosanoic acids agrees with the fact that elongation of fatty acids is driven from glucose [26]. In accordance with this observation, our previous study on the metabolism of HeLa cells in response to intracellular MRSA infection showed an activation in the glycolysis pathway [12].

Docosanoic acid

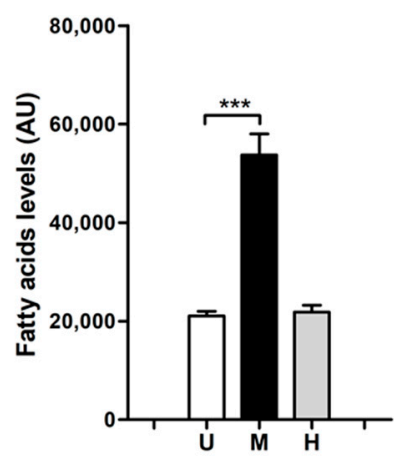

Palmitic acid

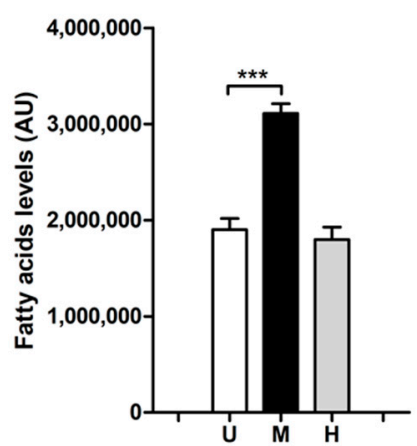

Eicosanoic acid

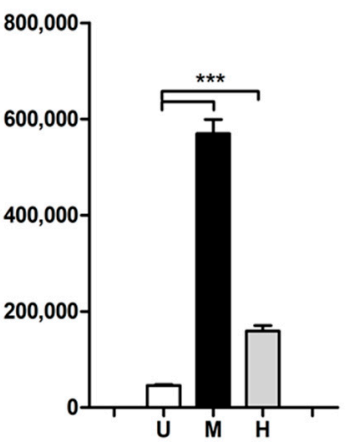

Stearic acid

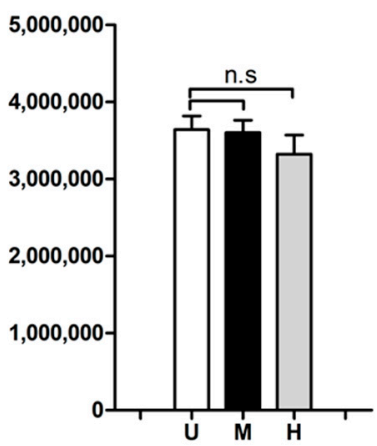

Figure 1. Absolute levels of lipid-bound docosanoic, eicosanoic and palmitic acid are affected after intracellular USA300 infection. HeLa cells were infected with USA300 and exposed to heat-killed USA300 (MOI 100; 6 h) and fatty acids levels were detected by GC-MS. Bar graphs show absolute levels of each fatty acid in uninfected cells (white bars), cells infected with USA300 strain (black bars) and cells exposed to heat-killed USA300 (grey bars). Data are expressed as means \pm standard error (SE) of three independent experiments performed in triplicates. One-way ANOVA and post hoc Tukey's multiple comparison tests were performed to assess statistically significance across treatments. $p$-value $\leq 0.001$ (***); n.s (no significant differences). $\mathrm{U}=$ Uninfected cells; $\mathrm{M}=$ methicillin-resistant Staphylococcus aureus (MRSA)-infected cells; $\mathrm{H}=$ cells exposed to heat-killed bacteria.

\subsection{Docosanoic, Eicosanoic and Palmitic Acids Showed a Cytoprotective Role in MRSA-Infected HeLa Cells}

We recently observed that the silencing of ELOVL1 during S. aureus infection leads to an increase of host cell death [27]. ELOVL1 participates in the production of very long-chain fatty acids synthesis by catalyzing the first reaction of their elongation cycle [28]. Hence, we hypothesized that the production of very long-chain fatty acids may have a cytoprotective role during cell infection. We therefore evaluated the impact of docosanoic, eicosanoic and palmitic acids on intracellular MRSA infection if given exogenously. To this end, we treated HeLa cells with $30 \mu \mathrm{M}$ of docosanoic, eicosanoic or palmitic acid and measured the host cell viability after MRSA infection. We employed stearic acid as an additional control, since the levels of this fatty acid were not increased in MRSA-infected cells (Figure 3). 


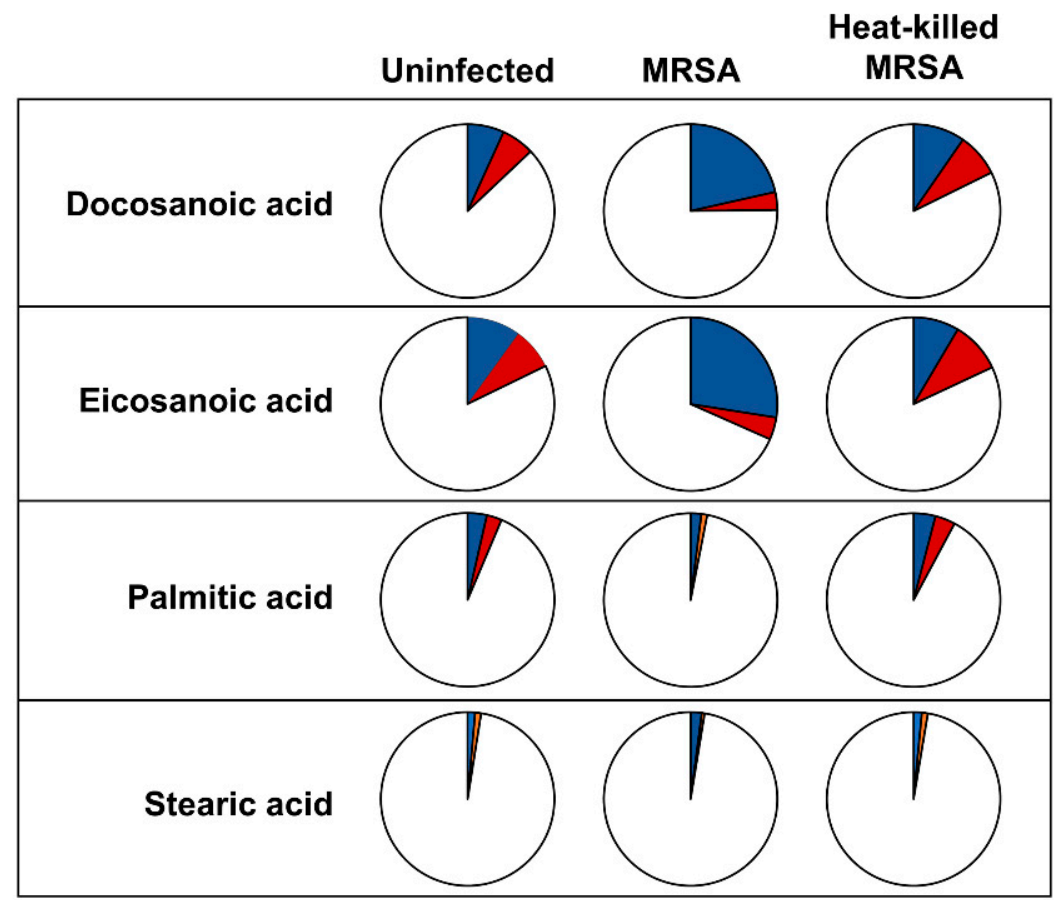

Figure 2. Labelling distribution of lipid-bound docosanoic, eicosanoic and palmitic acid is altered after intracellular USA300 infection. HeLa cells were infected with USA300 and exposed to heat-killed USA300 (MOI 100; 6 h) and labelling distribution was detected by GC-MS. Pie charts display the labelling pattern of transesterified fatty acids from uninfected cells (left pie-chart), cells infected with USA300 strain (middle pie-chart) and cells exposed to heat-killed USA300 (right pie-chart). Within pie-charts, blue slides represent carbon coming from labelled glucose, whereas red slides are carbon coming from labelled glutamine and white slides show carbon from other sources.

Uninfected

A

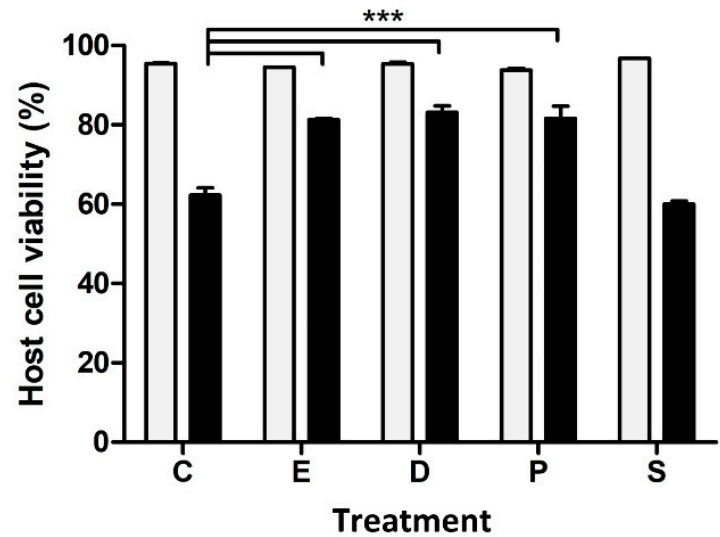

B

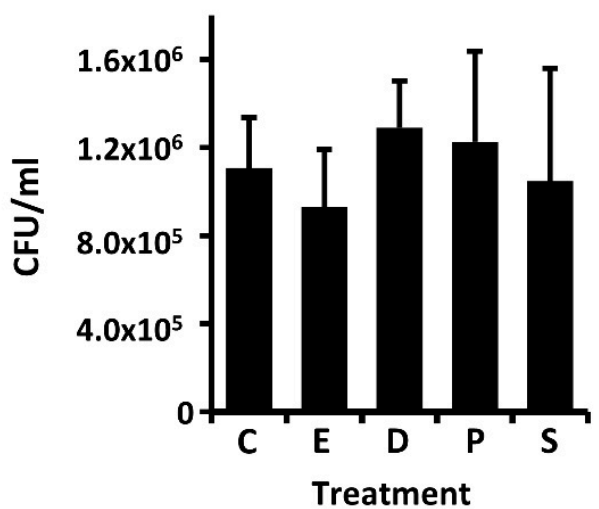

Figure 3. Treating HeLa cells with eicosanoic, docosanoic or palmitic acid increases host cell viability after USA300 infection but does not affect MRSA intracellular survival. HeLa cells were infected with USA300 (MOI 100; 6 h) in the presence of DMSO (C), docosanoic acid (D), eicosanoic acid (E), palmitic acid (P) and stearic acid (S), and host cell viability was quantified. (A) Quantification of host cell viability after USA300 infection was measured by flow cytometry using a double annexin V-FITC and PI staining. (B) Intracellular MRSA survival quantified by colony forming units per milliliter $(\mathrm{CFU} / \mathrm{mL})$. Data are expressed as means $\pm \mathrm{SE}$ of three independent experiments performed in duplicates. One-way ANOVA and post hoc Tukey's multiple comparison tests were performed to assess statistically significance across treatments. $p$-value $\leq 0.001\left(^{* * *}\right)$. 
When compared to the negative control (DMEM supplemented with DMSO), the host cell viability was significantly increased after MRSA infection when DMEM was supplemented with either docosanoic, eicosanoic or palmitic acids (Figure 3A). However, host cell viability was not restored when HeLa cells were treated with stearic acid (Figure 3A).

We speculated that host cell viability was partially restored in the presence of these saturated fatty acids due to a direct reduction or inhibition of bacterial growth. However, we did not detect any statistically significant changes when the intracellular MRSA survival was quantified across the different conditions (Figure 3B). In contrast, when we measured in vitro bacterial growth in Nutrient Broth medium supplemented with the aforementioned cytoprotective fatty acids we observed that MRSA growth at 6 and $8 \mathrm{~h}$ was significantly reduced in the presence of both docosanoic and palmitic acids (Figure 4). At $24 \mathrm{~h}$, MRSA growth was attenuated by all the cytoprotective fatty acids-docosanoic, eicosanoic and palmitic acids - but not by the presence of stearic acid in the medium (Figure 4B).

\section{A}
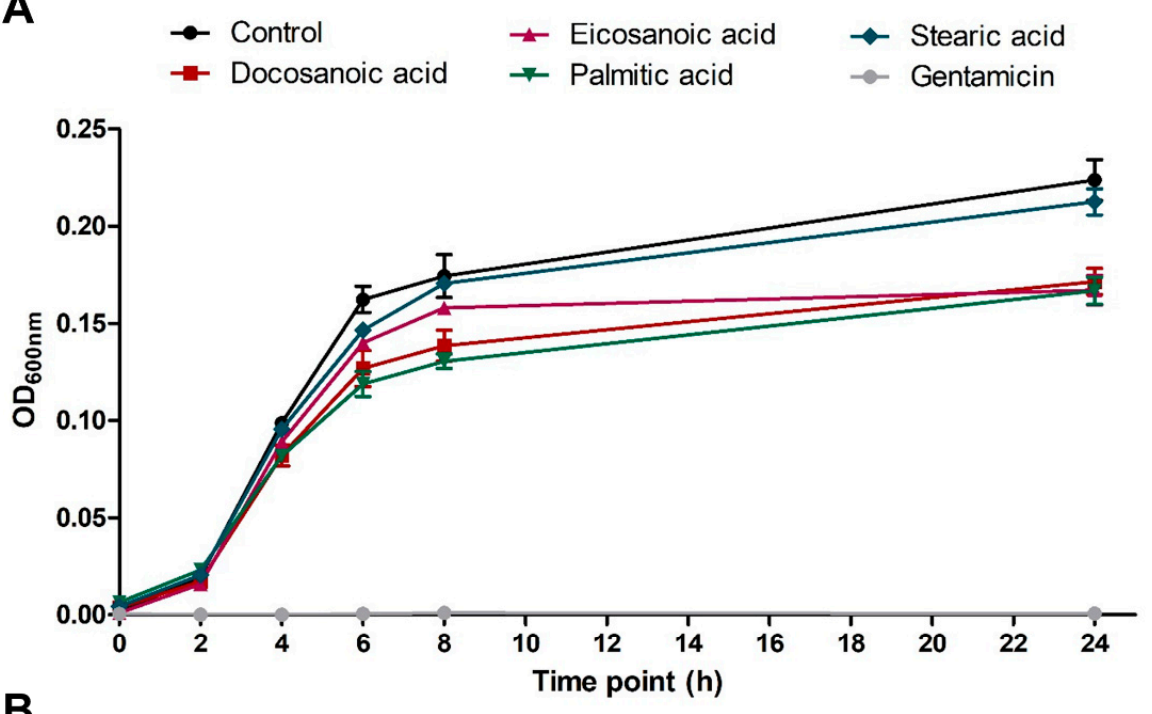

B
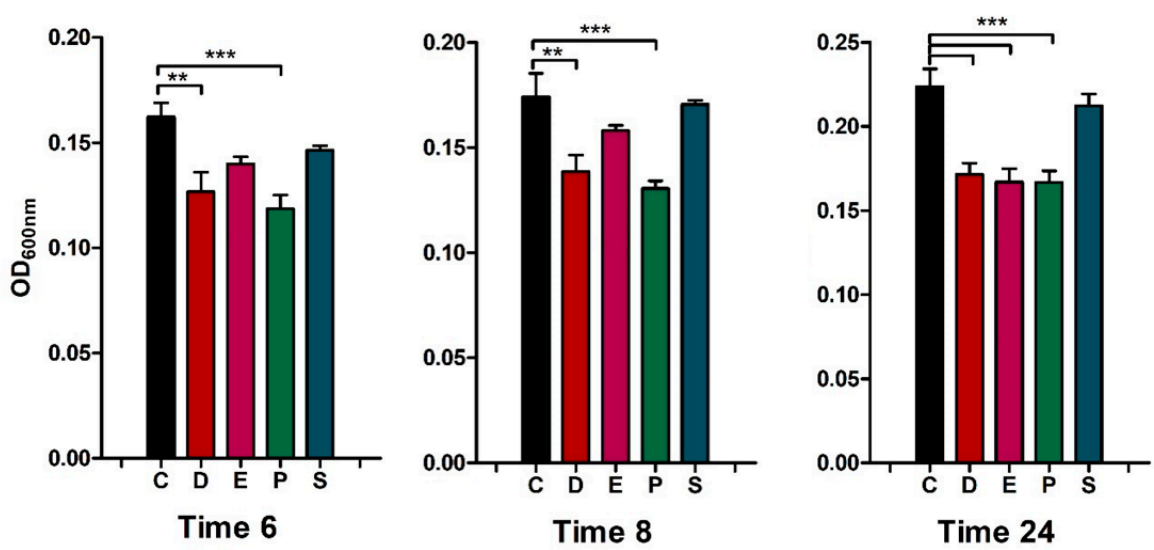

Figure 4. Eicosanoic, docosanoic and palmitic acid restricts in vitro USA300 growth in Nutrient Broth medium. (A) In vitro bacterial growth curves in Nutrient Broth and supplemented with DMSO (control), one fatty acid $(30 \mu \mathrm{M})$ and gentamicin $(100 \mu \mathrm{g} / \mathrm{mL})$ were evaluated by measuring the absorbance at 2, 4, 6, 8 and $24 \mathrm{~h}$. (B) In vitro bacterial growth at 6, 8 and $24 \mathrm{~h}$ in the presence of DMSO (C), docosanoic acid (D), eicosanoic acid (E), palmitic acid $(\mathbf{P})$ or stearic acid (S). Data are expressed as means \pm SE of three independent experiments performed in duplicates. One-way ANOVA and post hoc Tukey's multiple comparison tests were performed to assess statistically significance across treatments. $p$-value $\leq 0.01\left({ }^{* *}\right) ; \leq 0.001\left(^{* * *}\right)$. 
Overall, these results suggest that the increase of host cell viability after MRSA infection is due to the direct inhibition of MRSA growth in the presence of these three fatty acids, which antimicrobial activity may be bacteriostatic. This would explain why intracellular CFU counts were not altered across conditions, whilst bacterial in vitro growth was attenuated at long periods of incubation.

The antibacterial properties of lipids and fatty acids have been proposed since 1880s, when Robert Koch and his colleagues showed that specific fatty acids could inhibit the growth of Bacillus anthracis [29]. From then, many other studies have proven the bactericidal or bacteriostatic effect of several saturated and unsaturated fatty acids on Gram-positive and Gram-negative bacteria [20,30]. Nowadays, partially driven by the emergence of multidrug-resistant strains, the research on fatty acids and monoglycerides as potential antibacterial agents has gained new attention [30-36].

Fatty acids are amphipathic molecules that can promote membrane destabilization and pore formation, eventually leading to inhibition of bacterial growth or bacterial cell death. Targeting bacterial cell membrane is the key antibacterial effect of fatty acids and the mechanism of action includes: (i) increase in the membrane permeability, and consequently, cell lysis, (ii) disruption of the electron transport chain and uncoupling oxidative phosphorylation, and (iii) inhibition of membrane enzymes and nutrient uptake [30].

Specifically, several studies have shown that specific saturated and unsaturated fatty acids play an antibacterial role against $S$. aureus. As an example, topical administration of lauric acid have shown to be effective in vitro and in vivo to treat skin infections, caused by S. aureus and Propionibacterium acnes [37,38]. The delivery of antimicrobial lipids in highly concentrated forms-by formulation in liposomes or nanoparticles-has also been tested to treat Helicobacter pylori infection in vitro and in vivo [39-41]. Medium-chain length fatty acids, e.g., lauric acid are considered one of the most potent saturated fatty acid against Gram-positive bacteria, including Methicillin-susceptible Staphylococcus aureus (MSSA) and MRSA strains, albeit at high MOIs [21,42]. Similarly, treatment with arachidonic acid was effective against most Gram-positive bacteria, including S. aureus [43]. Furthermore, treatment with the linolenic acid also inhibits the growth of this pathogen [44]. The inhibition of bacterial cell growth by linolenic acid is achieved by increasing membrane permeability, which blocks macromolecular synthesis and disrupts the electron transport chain [45]. Some unsaturated fatty acids-including linolenic acid-have also shown antibacterial activity by inhibiting the enoyl-acyl carrier protein reductase (FabI), which is necessary for the fatty acid elongation process [46].

The three saturated fatty acids identified in this study-docosanoic, eicosanoic and palmitic acids-significantly reduced in vitro MRSA growth and restored host cell viability after infection. Nevertheless, the precise mechanism underlying the antibacterial activity of docosanoic, eicosanoic and palmitic acids remains unknown and further experiments need to be carried out to unravel the underlying mechanistic. It is, for example, currently unknown whether the fatty acids are bound to specific membranes of the host cell, e.g., the phagosome. Interestingly, certain host lipases may protect the infected cell against intracellular pathogenic bacteria by releasing antimicrobial lipids from the host cell membrane [47]. However, the cell response to the free fatty acids should be further characterized, as the observed protective effect on host cell viability may be due to other factors, such as a higher resistance to cellular death.

In summary, antibacterial fatty acids possess a great potential to combat bacterial infections. In addition, the combination of fatty acids along with existing therapies may increase their effect and could contribute to the reduction of antimicrobial resistance. The combination of free fatty acids and cholesteryl esters have been recently tested against Pseudomonas aeruginosa and Staphylococcus epidermidis, showing potential as novel antimicrobial agents [48]. 


\section{Materials and Methods}

\subsection{Bacterial Strains, Cell Lines and Culture Conditions}

S. aureus USA300 LAC strain [49] was cultured in Nutrient Broth (NB) medium (Sigma-Aldrich, Gillingham, UK). Routinely, bacteria were incubated at $37^{\circ} \mathrm{C}$, with vigorous shaking ( $\left.300 \mathrm{rpm}\right)$. For growth on solid medium, Nutrient Agar plates (NA; Sigma-Aldrich) were used and incubated at $37^{\circ} \mathrm{C}$.

To evaluate in vitro bacterial growth, $S$. aureus was incubated in 96-well plates with NB supplemented with either $100 \mu \mathrm{g} / \mathrm{mL}$ gentamycin or $30 \mu \mathrm{M}$ of docosanoic, eicosanoic, palmitic, or stearic acids; DMSO was used as negative control. Optical density at $600 \mathrm{~nm}\left(\mathrm{OD}_{600 \mathrm{~nm}}\right)$ was measured at different time points using an EL800 Microplate reader (Bio-Tek, Winooski, VT, USA).

For preinocula preparation, S. aureus USA300 LAC strain was grown overnight in $10 \mathrm{~mL}$ of NB at $37^{\circ} \mathrm{C}$ with shaking ( $300 \mathrm{rpm}$ ) and $0.5 \mathrm{~mL}$ of this culture was used to inoculate a flask containing $50 \mathrm{~mL}$ of NB. Bacterial cultures were grown until $\mathrm{OD}_{600 \mathrm{~nm}}$ of 1 was reached, upon which the culture was centrifuged ( $4000 \mathrm{rpm}, 15 \mathrm{~min}, 4^{\circ} \mathrm{C}$ ). Pellets were then washed twice with Dulbecco's Phosphate-Buffered Saline (DPBS), resuspended in $1.5 \mathrm{~mL}$ of PBS supplemented with $20 \%$ glycerol and aliquots of $100 \mu \mathrm{L}$ were stored at $-80^{\circ} \mathrm{C}$ until needed. Preinocula concentration was calculated by serial dilution plating and colony forming units (CFU) counting.

HeLa cells (ECACC 93021013) were grown in $100 \mathrm{~mm}$ cell culture plates (Sarstedt) with Dulbecco's Modified Eagle's medium (DMEM) containing pyruvate, glucose and glutamine and supplemented with $10 \%$ heat-inactivated foetal bovine serum (FBS) and $5 \%$ of penicillin and streptomycin solution, unless otherwise specified. Cells were incubated at $37^{\circ} \mathrm{C}$ and $5 \%$ of $\mathrm{CO}_{2}$ in a Heraeus ${ }^{\circledR} \mathrm{BB} 15$ incubator.

\subsection{Intracellular Infection Assays}

Intracellular MRSA infection assays were carried out as previously described [12,50]. For metabolomics approaches, HeLa cells were seeded in 6-well plates in DMEM without antibiotics at a cell density of $5 \times 10^{5}$ cells per well. For host cell viability assays, HeLa cells were seeded in 24-well plates in DMEM without antibiotics at a cell density of $7.5 \times 10^{4}$ cells per well. In both cases, cells were incubated overnight. The next day, an aliquot of bacterial preinocula was thawed, diluted in $900 \mu \mathrm{L}$ of PBS and centrifuged at $4000 \mathrm{rpm}$ for $5 \mathrm{~min}$. Pellet was washed twice with PBS prior to addition of DMEM without antibiotics at a bacterial density that corresponds to a multiplicity of infection (MOI) of 100. Then, the bacterial suspension supplemented with DMSO or $30 \mu \mathrm{M}$ of docosanoic, eicosanoic, palmitic, or stearic acids was added to each well, plates were centrifuged immediately at $1500 \mathrm{rpm}$ for $5 \mathrm{~min}$ and incubated at $37^{\circ} \mathrm{C}$ in $5 \% \mathrm{CO}_{2}$ for $45 \mathrm{~min}$ to allow bacterial internalization. The medium was then replaced by DMEM supplemented with DMSO or $30 \mu \mathrm{M}$ of the afore mentioned fatty acids and $100 \mu \mathrm{g} / \mathrm{mL}$ gentamycin to kill extracellular bacteria, and the plates were placed back in the incubator until the desired time points were reached.

\subsection{Host Cell and Bacterial Viability Assays}

Host cell viability was quantified after $6 \mathrm{~h}$ of infection as previously described [50]. Briefly, to recover both necrotic and apoptotic cells, supernatants of each well were transferred into clean Eppendorf's tubes. Cells were then trypsinized, diluted in DMEM without antibiotics, mixed with the supernatants and centrifuged at $1500 \mathrm{rpm}$ for $10 \mathrm{~min}$. Afterwards, cells were double stained with annexin V-FITC and propidium iodide according to manufacturer's recommendations (Becton Dickinson, BD; Wokingham, UK), diluted in $50 \mu \mathrm{L}$ of DMEM per sample and incubated for $15 \mathrm{~min}$ at room temperature. Stained cells were centrifuged at $1500 \mathrm{rpm}$ for $10 \mathrm{~min}$, supernatant was aspirated, and cell pellets were fixed using $150 \mu \mathrm{L}$ of BD Cytofix buffer (Becton Dickinson, BD; Wokingham, UK) for $15 \mathrm{~min}$ at $4{ }^{\circ} \mathrm{C}$. Finally, samples were diluted with $350 \mu \mathrm{L}$ of DMEM and host cell viability was measured by flow cytometry (BD Accuri ${ }^{\mathrm{TM}}$ C6 Plus). 
To quantify intracellular MRSA viability, infected HeLa cells were lysed at $6 \mathrm{~h}$ post infection with $0.1 \%$ Triton X-100 diluted in PBS. The samples were then serially diluted and plated on Nutrient Agar for $\mathrm{CFU} / \mathrm{mL}$ determination.

\subsection{Samples Preparation for Intracellular Metabolome Analysis}

After $6 \mathrm{~h}$ of infection, cells were washed with $1 \mathrm{~mL}$ of ice-cold Ringer's solution and quenched by adding $1 \mathrm{~mL}$ of cold $\left(-20^{\circ} \mathrm{C}\right)$ LC-MS grade methanol [51]. Cells were then detached by using a cell scraper and the cold methanol suspension was transferred into a clean Eppendorf tube. Extraction was repeated with a further $0.5 \mathrm{~mL}$ of cold methanol and extracts were pooled and stored at $-80^{\circ} \mathrm{C}$.

To obtain the organic fraction, extracts were first dried using an Eppendorf Vacufuge Concentrator. A dual phase extraction was performed by adding $300 \mu \mathrm{L}$ of $\mathrm{CHCl}_{3} / \mathrm{MeOH}(2: 1)$ and vortexing for $30 \mathrm{~s}$. After addition of $300 \mu \mathrm{L}$ of water and centrifugation $(13,000 \mathrm{rpm}, 10 \mathrm{~min}, \mathrm{RT})$, the lower organic layers were placed into glass vials and dried overnight before being stored at $-80^{\circ} \mathrm{C}$.

For derivatization, the organic fraction was reconstituted in $300 \mu \mathrm{L}$ of methanol/toluene solution (1:1 ratio), treated with $200 \mu \mathrm{L}$ of $0.5 \mathrm{M}$ sodium methoxide and incubated for $1 \mathrm{~h}$ at room temperature. Reaction was stopped by adding $500 \mu \mathrm{L}$ of $1 \mathrm{M} \mathrm{NaCl}$ and $25 \mu \mathrm{L}$ of concentrated $\mathrm{HCl}$. Fatty acids were extracted by using $500 \mu \mathrm{L}$ of hexane and organic layers were dried in the fume cupboard under $\mathrm{N}_{2}$. Organic samples were then derivatized with $40 \mu \mathrm{L}$ acetonitrile and $40 \mu \mathrm{L}$ of $\mathrm{N}$-(tert-butyldimethylsilyl)-N-methyltrifluro-acetamide (MBTSFA; Thermo Fisher Scientific, Waltham, MA, USA) and incubated at $70{ }^{\circ} \mathrm{C}$ for $1 \mathrm{~h}$. Samples were finally centrifuged at $2000 \mathrm{rpm}$ for $5 \mathrm{~min}$ prior to transferring them into a clean vial for GC-MS analysis.

\subsection{Gas Chromatography-Mass Spectrometry (GC-MS)}

GC-MS analysis was performed as previously described [12]. Briefly, analysis was carried out on an Agilent 7890 GC equipped with a $30 \mathrm{~m}$ DB-5MS capillary column with a $10 \mathrm{~m}$ Duraguard column connected to an Agilent 5975 MSD operating under electron impact (EI) ionization (Agilent Technologies, Santa Clara, CA, USA). Samples were injected with an Agilent 7693 autosampler injector into deactivated spitless liners using helium as the carrier gas [24].

Metabolites were identified and quantified using a workflow described previously [52]. Samples were deconvoluted in AMDIS $[53,54]$ and quantified using an in-house script. Integration of labelled metabolites was carried out based on an in-house fragment/retention time database using an updated version of the Matlab script capable of natural isotope correction $[24,55]$.

\subsection{Statistical Analysis}

Statistical analysis was conducted using GraphPad Prism software. One-way ANOVA and post hoc Tukey's multiple comparison tests were employed to examine significant differences across treatments.

\section{Conclusions}

The host-lipidome is altered in response to intracellular MRSA infection. We found that the absolute levels of docosanoic, eicosanoic, and palmitic acids are significantly increased in MRSA-infected cells. Interestingly, we observed that host cell viability is partially restored after MRSA infection in the presence of these three fatty acids, while in vitro bacterial growth is hampered. Therefore, docosanoic, eicosanoic and stearic acids seems to play a cytoprotective role in HeLa cells due to direct reduction of MRSA in vitro growth. Further research is needed to fully elucidate the antibacterial mechanism of action of these three fatty acids. 
Supplementary Materials: The following are available online at http://www.mdpi.com/2218-1989/9/7/148/s1, Figure S1: Absolute levels of arachidonic, linoleic, myristic, oleic and palmitoleic acids after intracellular USA300 infection, Figure S2: Labelling distribution of arachidonic, linoleic, myristic, oleic and palmitoleic acids after intracellular USA300 infection, Figure S3: Isotopologue distribution of eicosanoic acid.

Author Contributions: Conceptualization, V.B. and M.L.; methodology, J.K.E., V.B. and M.L.; software, N.B.-S. and V.B.; validation, N.B.-S.; formal analysis, N.B.-S.; investigation, N.B.-S., V.B. and M.L.; resources, H.C.K., V.B. and M.L.; data curation, N.B.-S. and V.B.; writing-original draft preparation, N.B.-S.; writing-review and editing, J.K.E., Y.C., H.C.K., V.B. and M.L.; visualization, N.B.-S. and V.B.; supervision, Y.C., V.B. and M.L.; project administration, V.B. and M.L.; funding acquisition, V.B. and M.L.

Funding: This work was supported by a Roehampton Vice Chancellor's Scholarship to N.B.-S. and intramural funding from the University of Roehampton to V.B. and M.L.

Acknowledgments: We thank Cokro Leksmono and Martha Villegas-Montes for technical assistance.

Conflicts of Interest: The authors declare no conflict of interest.

\section{References}

1. Lowy, F.D. Staphylococcus aureus infections. N. Engl. J. Med. 1998, 339, 520-532. [CrossRef]

2. Wertheim, H.F.; Melles, D.C.; Vos, M.C.; van Leeuwen, W.; van Belkum, A.; Verbrugh, H.A.; Nouwen, J.L. The role of nasal carriage in Staphylococcus aureus infections. Lancet Infect. Dis. 2005, 5, 751-762. [CrossRef]

3. Lowy, F.D. Is Staphylococcus aureus an intracellular pathogen? Trends Microbiol. 2000, 8, 341-343. [CrossRef]

4. Sendi, P.; Proctor, R.A. Staphylococcus aureus as an intracellular pathogen: The role of small colony variants. Trends Microbiol. 2009, 17, 54-58. [CrossRef] [PubMed]

5. Garzoni, C.; Kelley, W.L. Staphylococcus aureus: New evidence for intracellular persistence. Trends Microbiol. 2009, 17, 59-65. [CrossRef]

6. Fraunholz, M.; Sinha, B. Intracellular Staphylococcus aureus: Live-in and let die. Front. Cell. Infect. Microbiol. 2012, 2, 1-10. [CrossRef] [PubMed]

7. Lehar, S.M.; Pillow, T.; Xu, M.; Staben, L.; Kajihara, K.K.; Vandlen, R.; DePalatis, L.; Raab, H.; Hazenbos, W.L.; Hiroshi Morisaki, J.; et al. Novel antibody-antibiotic conjugate eliminates intracellular S. aureus. Nature 2015, 527, 323-328. [CrossRef]

8. Abu Kwaik, Y.; Bumann, D. Host delivery of favorite meals for intracellular pathogens. PLoS Pathog. 2015, 11, e1004866. [CrossRef]

9. Dandekar, T.; Eisenreich, W. Host-adapted metabolism and its regulation in bacterial pathogens. Front. Cell. Infect. Microbiol. 2015, 5, 27-28. [CrossRef]

10. Eisenreich, W.; Heesemann, J.; Rudel, T.; Goebel, W. Metabolic host responses to infection by intracellular bacterial pathogens. Front. Cell. Infect. Microbiol. 2013, 3, 1-22. [CrossRef]

11. Olive, A.J.; Sassetti, C.M. Metabolic crosstalk between host and pathogen: Sensing, adapting and competing. Nat. Rev. Microbiol. 2016, 14, 221-234. [CrossRef] [PubMed]

12. Bravo-Santano, N.; Ellis, J.K.; Mateos, L.M.; Calle, Y.; Keun, H.C.; Behrends, V.; Letek, M. Intracellular Staphylococcus aureus modulates host central carbon metabolism to activate autophagy. mSphere 2018, 3, e00374-18. [CrossRef] [PubMed]

13. Eisenreich, W.; Dandekar, T.; Heesemann, J.; Goebel, W. Carbon metabolism of intracellular bacterial pathogens and possible links to virulence. Nat. Rev. Microbiol. 2010, 8, 401-412. [CrossRef] [PubMed]

14. Escoll, P.; Song, O.R.O.-R.; Viana, F.; Steiner, B.; Lagache, T.; Olivo-Marin, J.-C.J.C.; Impens, F.; Brodin, P.; Hilbi, H.; Buchrieser, C. Legionella pneumophila modulates mitochondrial dynamics to trigger metabolic repurposing of infected macrophages. Cell Host Microbe 2017, 22, 302-316. [CrossRef] [PubMed]

15. Kentner, D.; Martano, G.; Callon, M.; Chiquet, P.; Brodmann, M.; Burton, O.; Wahlander, A.; Nanni, P.; Delmotte, N.; Grossmann, J.; et al. Shigella reroutes host cell central metabolism to obtain high-flux nutrient supply for vigorous intracellular growth. Proc. Natl. Acad. Sci. USA 2014, 111, 9929-9934. [CrossRef]

16. Pandey, A.K.; Sassetti, C.M. Mycobacterial persistence requires the utilization of host cholesterol. Proc. Natl. Acad. Sci. USA 2008, 105, 4376-4380. [CrossRef] [PubMed]

17. Gierok, P.; Harms, M.; Methling, K.; Hochgräfe, F.; Lalk, M. Staphylococcus aureus infection reduces nutrition uptake and nucleotide biosynthesis in a human airway epithelial cell line. Metabolites 2016, 6, 41. [CrossRef] 
18. Quehenberger, O.; Armando, A.M.; Dennis, E.A. High sensitivity quantitative lipidomics analysis of fatty acids in biological samples by gas chromatography-mass spectrometry. Biochim. Biophys. Acta 2011, 1811, 648-656. [CrossRef]

19. Porter, E.; Ma, D.C.; Alvarez, S.; Faull, K.F. Antimicrobial lipids: Emerging effector molecules of innate host defense. World J. Immunol. 2015, 5, 51. [CrossRef]

20. Desbois, A.P.; Smith, V.J. Antibacterial free fatty acids: Activities, mechanisms of action and biotechnological potential. Appl. Microbiol. Biotechnol. 2010, 85, 1629-1642. [CrossRef]

21. Kabara, J.O.N.J.; Swieczkowski, D.M.; Conley, A.J.; Truant, J.P. Fatty acids and derivatives as antimicrobial agents. Antimicrob. Agents Chemother. 1972, 2, 23-28. [CrossRef] [PubMed]

22. Dennis, E.A.; Norris, P.C. Eicosanoid storm in infection and inflammation. Nat. Rev. Immunol. 2015, 15, 511-523. [CrossRef] [PubMed]

23. Sen, S.; Sirobhushanam, S.; Johnson, S.R.; Song, Y.; Tefft, R.; Gatto, C.; Wilkinson, B.J. Growth-environment dependent modulation of Staphylococcus aureus Branched-Chain to Straight-Chain fatty acid ratio and incorporation of unsaturated fatty acids. PLOS ONE 2016, 11, e0165300. [CrossRef] [PubMed]

24. Tredwell, G.D.; Keun, H.C. ConvISA: A simple, convoluted method for isotopomer spectral analysis of fatty acids and cholesterol. Metab. Eng. 2015, 32, 125-132. [CrossRef] [PubMed]

25. Argus, J.P.; Wilks, M.Q.; Zhou, Q.D.; Hsieh, W.Y.; Khialeeva, E.; Hoi, X.P.; Bui, V.; Xu, S.; Yu, A.K.; Wang, E.S.; et al. Development and application of FASA, a model for quantifying fatty acid metabolism using stable isotope labeling. Cell Rep. 2018, 25, 2919-2934.e8. [CrossRef] [PubMed]

26. Pietrocola, F.; Galluzzi, L.; Bravo-San Pedro, J.M.; Madeo, F.; Kroemer, G. Acetyl coenzyme A: A central metabolite and second messenger. Cell Metab. 2015, 21, 805-821. [CrossRef]

27. Bravo-Santano, N.; Calle, Y.; Behrends, V.; Letek, M. Hijacking of host cellular functions in Staphylococcus aureus infections. In Proceedings of the Oral Presentation at the International Symposium on Staphylococci and Staphylococcal Infections, University of Copenhagen, Copenhagen, Denmark, 23-26 August 2018.

28. Jakobsson, A.; Westerberg, R.; Jacobsson, A. Fatty acid elongases in mammals: Their regulation and roles in metabolism. Prog. Lipid Res. 2006, 45, 237-249. [CrossRef]

29. Thormar, H. Lipids and Essential Oils; John Wiley \& Sons Ltd.: Hoboken, NJ, USA, 2010; ISBN 9780470741788.

30. Yoon, B.K.; Jackman, J.A.; Valle-Gonz, E.R.; Cho, N. Antibacterial free fatty acids and monoglycerides: Biological activities, experimental testing, and therapeutic applications. Int. J. Mol. Sci. 2018, 19, 1114. [CrossRef]

31. Watanabe, T.; Yamamoto, Y.; Miura, M.; Konno, H.; Yano, S.; Nonomura, Y. Systematic analysis of selective bactericidal activity of fatty acids against Staphylococcus aureus with minimum inhibitory concentration and minimum bactericidal concentration. J. Oleo Sci. 2019, 68, 291-296. [CrossRef]

32. Cartron, M.L.; England, S.R.; Chiriac, A.I.; Josten, M.; Turner, R.; Rauter, Y.; Hurd, A.; Sahl, H.G.; Jones, S.; Foster, S.J. Bactericidal activity of the human skin fatty acid cis-6-hexadecanoic acid on Staphylococcus aureus. Antimicrob. Agents Chemother. 2014, 58, 3599-3609. [CrossRef]

33. Yamamoto, Y.; Kawamura, Y.; Yamazaki, Y.; Kijima, T.; Morikawa, T.; Nonomura, Y. Palmitoleic acid calcium salt: A lubricant and bactericidal powder from natural lipids. J. Oleo Sci. 2015, 64, 283-288. [CrossRef] [PubMed]

34. Yamamoto, Y.; Morikawa, T.; Kawai, T.; Nonomura, Y. Selective bactericidal activity of divalent metal salts of lauric acid. ACS Omega 2017, 2, 113-121. [CrossRef] [PubMed]

35. Morikawa, T.; Yamamoto, Y.; Nonomura, Y. Effect of $\mathrm{pH}$ on bactericidal activities of calcium laurate. J. Oleo Sci. 2018, 67, 859-862. [CrossRef] [PubMed]

36. Yamamoto, Y.; Kijima, T.; Morikawa, T.; Nonomura, Y. Lubricant and bactericidal properties of calcium salts of fatty acids: Effect of degree of unsaturation. J. Oleo Sci. 2015, 64, 1095-1100. [CrossRef] [PubMed]

37. Chen, C.-H.; Wang, Y.; Nakatsuji, T.; Liu, Y.; Zouboulis, C.C.; Gallo, R.L.; Zhang, L.; Hsieh, M.; Huang, C. An innate bactericidal oleic acid effective against skin infection of methicillin-resistant Staphylococcus aureus: A therapy concordant with evolutionary medicine. J. Microbiol. Biotechnol. 2011, 21, 391-399. [PubMed]

38. Pornpattananangkul, D.; Fu, V.; Thamphiwatana, S.; Zhang, L.; Chen, M.; Vecchio, J.; Gao, W.; Huang, C.-M.; Zhang, L. In vivo treatment of Propionibacterium acnes infection with liposomal lauric acids. Adv. Healthc. Mater. 2013, 2, 1322-1328. [CrossRef] [PubMed] 
39. Obonyo, M.; Zhang, L.; Thamphiwatana, S.; Pornpattananangkul, D.; Fu, V.; Zhang, L. Antibacterial activities of liposomal linolenic acids against antibiotic-resistant Helicobacter pylori. Mol. Pharm. 2012, 9, 2677-2685. [CrossRef]

40. Thamphiwatana, S.; Gao, W.; Obonyo, M.; Zhang, L. In vivo treatment of Helicobacter pylori infection with liposomal linolenic acid reduces colonization and ameliorates inflammation. Proc. Natl. Acad. Sci. USA 2014, 111, 17600-17605. [CrossRef]

41. Seabra, C.L.; Nunes, C.; Gomez-Lazaro, M.; Correia, M.; Machado, J.C.; Gonçalves, I.C.; Reis, C.A.; Reis, S.; Martins, M.C.L. Docosahexaenoic acid loaded lipid nanoparticles with bactericidal activity against Helicobacter pylori. Int. J. Pharm. 2017, 73, 128-137. [CrossRef]

42. Kitahara, T.; Koyama, N.; Matsuda, J.; Aoyama, Y.; Hirakata, Y.; Kamihira, S.; Kohno, S.; Nakashima, M.; Sasaki, H. Antimicrobial activity of saturated fatty acids and fatty amines against Methicillin-Resistant Staphylococcus aureus. Biol. Pharm. Bull. 2004, 27, 1321-1326. [CrossRef]

43. Knapp, H.R.; Melly, M.A. Bactericidal effects of polyunsaturated fatty acids. J. Infect. Dis. 1986, 154, 84-94. [CrossRef] [PubMed]

44. Lee, J.-Y.; Kim, Y.-S.; Shin, D.-H. Antimicrobial synergistic effect of linolenic acid and monoglyceride against Bacillus cereus and Staphylococcus aureus. J. Agric. Food Chem. 2002, 50, 2193-2199. [CrossRef] [PubMed]

45. Greenway, D.; Dyke, K. Mechanism of the inhibitory action of linoleic acid on the growth of Staphylococcus aureus. J. Gen. Microbiol. 1979, 115, 233-245. [CrossRef] [PubMed]

46. Zheng, C.J.; Yoo, J.-S.; Lee, T.-G.; Cho, H.-Y.; Kim, Y.-H.; Kim, W.-G. Fatty acid synthesis is a target for antibacterial activity of unsaturated fatty acids. FEBS Lett. 2005, 579, 5157-5162. [CrossRef] [PubMed]

47. Das, U.N. Arachidonic acid and other unsaturated fatty acids and some of their metabolites function as endogenous antimicrobial molecules: A review. J. Adv. Res. 2018, 11, 57-66. [CrossRef] [PubMed]

48. Cheung Lam, A.H.; Sandoval, N.; Wadhwa, R.; Gilkes, J.; Do, T.Q.; Ernst, W.; Chiang, S.-M.; Kosina, S.; Xu, H.H.; Fujii, G.; et al. Assessment of free fatty acids and cholesteryl esters delivered in liposomes as novel class of antibiotic. BMC Res. Notes 2016, 9, 337. [CrossRef] [PubMed]

49. Edwards, A.M. Phenotype switching is a natural consequence of Staphylococcus aureus replication. J. Bacteriol. 2012, 194, 5404-5412. [CrossRef] [PubMed]

50. Bravo-Santano, N.; Stölting, H.; Cooper, F.; Bileckaja, N.; Majstorovic, A.; Ihle, N.; Mateos, L.M.; Calle, Y.; Behrends, V.; Letek, M. Host-directed kinase inhibitors act as novel therapies against intracellular Staphylococcus Aureus. Sci. Rep. 2019, 9, 4876. [CrossRef]

51. Sellick, C.A.; Hansen, R.; Maqsood, A.R.; Dunn, W.B.; Stephens, G.M.; Goodacre, R.; Dickson, A.J. Effective quenching processes for physiologically valid metabolite profiling of suspension cultured mammalian cells. Anal. Chem. 2009, 81, 174-183. [CrossRef]

52. Behrends, V.; Giskeødegård, G.F.; Bravo-Santano, N.; Letek, M.; Keun, H.C. Acetaminophen cytotoxicity in HepG2 cells is associated with a decoupling of glycolysis from the TCA cycle, loss of NADPH production, and suppression of anabolism. Arch. Toxicol. 2019, 93, 341-353. [CrossRef]

53. Kind, T.; Wohlgemuth, G.; Lee, D.Y.; Lu, Y.; Palazoglu, M.; Shahbaz, S.; Fiehn, O. FiehnLib—Mass spectral and retention index libraries for metabolomics based on quadrupole and time-of-flight gas chromatography/mass spectrometry. Anal. Chem. 2009, 81, 10038-10048. [CrossRef] [PubMed]

54. Stein, S.E. An integrated method for spectrum extraction and compound identification from gas chromatography/mass spectrometry data. J. Am. Soc. Mass Spectrom. 1999, 10, 770-781. [CrossRef]

55. Behrends, V.; Tredwell, G.D.; Bundy, J.G. A software complement to AMDIS for processing GC-MS metabolomic data. Anal. Biochem. 2011, 415, 206-208. [CrossRef] [PubMed]

(C) 2019 by the authors. Licensee MDPI, Basel, Switzerland. This article is an open access article distributed under the terms and conditions of the Creative Commons Attribution (CC BY) license (http://creativecommons.org/licenses/by/4.0/). 